\title{
Thermal requirements of Trichogramma pretiosum (Hymenoptera: Trichogrammatidae) lines in Neoleucinodes elegantalis (Lepidoptera: Crambidae) eggs
}

\author{
Requerimientos térmicos de las líneas de Trichogramma pretiosum (Hymenoptera: \\ Trichogrammatidae) en huevos de Neoleucinodes elegantalis (Lepidoptera: Crambidae) \\ CRISTIANE RAMOS COUTINHO ${ }^{1}$; SUYANNE ARAÚJO DE SOUZA²; \\ ANTÔNIA DÉBORA DOS SANTOS PONTES ${ }^{3}$; MAURICIO SEKIGUCHI DE \\ GODOY $^{4}$; FABRICIO FAGUNDES PEREIRA ${ }^{5}$; PATRIK LUIZ PASTORI ${ }^{6}$
}

\begin{abstract}
${ }^{1} \mathrm{Ph}$. D. in Agronomy/Entomology, IN Soluções Biológicas LTDA., Fortaleza, Ceará State, Brazil, cristiane.coutinho@inbiologicas.com.br, https://orcid. org/0000-0002-7870-904X. ² Engineer Agronomist. Universidade Estadual Paulista "Julio de Mesquita Filho" - UNESP, Faculdade de Ciências Agronômicas, Câmpus de Botucatu, Botucatu, São Paulo State, Brazil, suyanne-araujo@hotmail.com, https://orcid.org/0000-0001-5524-6989. ${ }^{3}$ Student in Agronomy. Universidade Federal do Ceará - UFC, Departamento de Fitotecnia, Fortaleza, Ceará State, Brazil, santosp.debora@gmail.com, https://orcid.org/0000-00015299-2783. ${ }^{4} \mathrm{Ph}$. D. in Agronomy/Entomology, Universidade Federal Rural do Semi-Árido - UFERSA, Centro de Ciências Agrárias, Departamento de Ciências Agronômicas e Florestais, Mossoró, Rio Grande do Norte State, Brazil, msdgodoy@ufersa.edu.br, https://orcid.org/0000-0002-3842-340X. ${ }^{5}$ Ph. D. in Entomology, Universidade Federal da Grande Dourados - UFGD, Faculdade de Ciências Biológicas e Ambientais, Rodovia Dourados/Itahum, Dourados, Mato Grosso do Sul State, Brazil, fabriciofagundes@ufgd.edu.br, https://orcid.org/0000-0003-1638-7409. ${ }^{6} \mathrm{Ph}$. D. in Agronomy/Entomology. Universidade Federal do Ceará - UFC, Departamento de Fitotecnia, Fortaleza, Ceará State, Brazil, plpastori@ufc.br, https://orcid.org/0000-0003-1892-8029.
\end{abstract}

\section{Corresponding author}

Patrik Luiz Pastori. Ph. D. in Agronomy/Entomology. Universidade Federal do Ceará - UFC, Departamento de Fitotecnia, Av. Mister Hull, ${ }^{\circ}$ 2977, CEP: 60.356-001; Fortaleza, Ceará State, Brazil,plpastori@ufc.br,https://orcid.org/00000003-1892-8029.

\section{Suggested citation}

COUTINHO, C. R.; SOUZA, S. A.; PONTES, A. D. S.; GODOY, M. S.; PEREIRA, F. F.; PASTORI, P. L. 2021. Thermal requirements of Trichogramma pretiosum (Hymenoptera: Trichogrammatidae) lines in Neoleucinodes elegantalis (Lepidoptera: Crambidae) eggs. Revista Colombiana de Entomología 47 (1): e8548. https://doi.org/10.25100/socolen.v47i1.8548

Received: 24-Sep-2019

Accepted: 19-Jun-2020

Published: 3-Feb-2021

Revista Colombiana de Entomología ISSN (Print): 0120-0488

ISSN (On Line): 2665-4385

$\mathrm{https} / /$ revistacolombianaentomologia.univalle.edu.co

Open access

(c) (i) (2) (2) BY-NC-SA 4.0

Publishers: Sociedad Colombiana de Entomología SOCOLEN (Bogotá, D. C., Colombia) https://www.socolen.org.co

Universidad del Valle (Cali, Colombia)

https://www.univalle.edu.co

(C) 2021 Sociedad Colombiana de Entomología - SOCOLEN y Universidad del Valle - Univalle
Abstract: This study aimed to evaluate the impact of temperature on the development of two lines of Trichogramma pretiosum (Hymenoptera: Trichogrammatidae), to determine the thermal requirements of this parasitoid wasp on Neoleucinodes elegantalis (Lepidoptera: Crambidae) eggs. The experiment was carried out with two lines ("Ubajara" and "Guaraciaba", Ceará State) of $T$. pretiosum collected naturally parasitizing eggs of $N$. elegantalis in tomato (Solanum lycopersicum) fruits. In this experiment, 40 eggs of the host $N$. elegantalis and 4 females of the parasitoids were used, with exposure to parasitism for 24 hours at $25 \pm 1{ }^{\circ} \mathrm{C}$, relative humidity of $70 \pm 10 \%$, and 12-h photophase. At the end of this period, females were removed and the tubes were transferred to incubators ( $\mathrm{RH}=70 \pm 10 \% ; 12$-h photophase), exposed to 15,20 , 25,30 , or $35^{\circ} \mathrm{C}$, until emergence of the following generation of the parasitoids. The percentage of emergence, sex ratio, the number of parasitoids that emerged per egg, and cycle duration were assessed. The experiments were set up in a completely randomized experimental design with 5 treatments (temperatures) and 12 replicates. ANOVA was conducted and the means were compared by Tukey test $(\mathrm{P}<0.05)$. The base temperatures were $10.77^{\circ} \mathrm{C}$ and $10.86{ }^{\circ} \mathrm{C}$ and the number of generations per year were 33.29 and 35.63 for "Ubajara" and "Guaraciaba", respectively. The study showed that temperature changed the biological parameters, and cycle duration of the "Ubajara" and "Guaraciaba" lines decreased as temperature increased.

Keywords: Tomato fruit borer, egg parasitoids, biological parameters, base temperature, Trichogramma pretiosum, Neoleucinodes elegantalis, Trichogrammatidae, Crambidae.

Resumen: El objetivo de este estudio fue evaluar el impacto de la temperatura en el desarrollo de dos líneas de Trichogramma pretiosum (Hymenoptera: Trichogrammatidae), para determinar los requisitos térmicos de este parasitoide en huevos de Neoleucinodes elegantalis (Lepidoptera: Crambidae). El experimento se llevó a cabo con dos líneas ("Ubajara" y "Guaraciaba", Ceará) de T. pretiosum a partir de huevos parasitarios de $N$. elegantalis en frutos de tomate (Solanum lycopersicum). En este experimento, se usaron 40 huevos del huésped $N$. elegantalis y 4 hembras de los parasitoides, con exposición al parasitismo durante 24 horas (a $25 \pm 1{ }^{\circ} \mathrm{C}, 70 \pm 10 \%$ de HR y fotofase de $12 \mathrm{~h}$ ). Al final de este período, se retiraron las hembras y los tubos se transfirieron a incubadoras $(\mathrm{HR}=70 \pm 10 \%$ y fotofase de $12 \mathrm{~h}$, a 15,20 , 25,30 o $35^{\circ} \mathrm{C}$, hasta la aparición de la generación siguiente de parasitoides. Los parámetros evaluados fueron el porcentaje de emergencia, la proporción de sexos, el número de parasitoides que surgieron por huevo y la duración del ciclo. Los experimentos se establecieron en un diseño experimental completamente al azar con cinco tratamientos (temperaturas) y 12 repeticiones. Se realizó ANOVA y se compararon las medias mediante la prueba de Tukey $(\mathrm{P}<0.05)$. La temperatura base fue de 10,77 y $10,86^{\circ} \mathrm{C}$ y el número de generaciones por año fue de 33,29 y 35,63 para "Ubajara" y "Guaraciaba", respectivamente. La temperatura cambió los parámetros biológicos, y la duración del ciclo de las líneas "Ubajara" y "Guaraciaba" disminuyó a medida que aumentaba la temperatura.

Palabras clave: Barrenador de la fruta del tomate, parasitoides de huevo, parámetros biológicos, temperatura base, Trichogramma pretiosum, Neoleucinodes elegantalis, Trichogrammatidae, Crambidae. 


\section{Introduction}

Tomato (Solanum lycopersicum L.) is a vegetable crop of economic and social importance, due to the scale of production and job creation (Barros et al. 2014; Gomes and Castro 2017). Tomato is grown in all regions of Brazil, occupying a total area of 63,300 hectares (Instituto Brasileiro de Geografia e Estatística 2018). Tomato production requires a high financial investment, due to broad susceptibility to physiological disorders, infection from plant pathogens, a high application in inputs and services, and attack from insect pests (Loos et al. 2008).

One of the most prominent pests is the tomato fruit borer Neoleucinodes elegantalis (Guenée, 1854) (Lepidoptera: Crambidae) due to the damages it brings about in fruit, leaving it unsuitable for consumption and industrial processes (Gravena and Benvenga 2003; Picanço et al. 2007).

Females of $N$. elegantalis lay eggs on the calyx or green fruit of $2 \mathrm{~cm}$ diameter. After emergence, larvae penetrate and develop within the fruit, thus remaining protected, making the adoption of several control methods unfeasible (Benvenga et al. 2010; Fornazier et al. 2010; Moura et al. 2014).

In accordance with the habit of the insect pest, a control alternative is the use of parasitoid wasps Trichogramma (Hymenoptera: Trichogrammatidae), because they parasitize the eggs of $N$. elegantalis, impeding the larval emergence and, consequently, the injuries they cause (Berti and Marcano 1991; Oliveira et al. 2020).

Species of Trichogramma are biological control agents associated mainly with parasitizing eggs of Lepidoptera pests. In Brazil, Trichogramma pretiosum Riley, 1879 is widely distributed species, and is often found worldwide (Goulart et al. 2008; Wajnberg 2010).

The success of biological control programs with Trichogramma species depends on several factors, including, particularly, the control potential of the species and/or line, the insect pest, and the effect of climate conditions (Pastori et al. 2008; 2012a; Moreira et al. 2009).

The choice of the species/line is of utmost importance since parasitoids of the genus Trichogramma may have interand intraspecific genetic variations, leading to differences in search strategy, host selection, and tolerance to environmental conditions (Pastori et al. 2008; Siqueira et al. 2012).

Thus, to ensure the success of inundative releases of Trichogramma, it is essential to select the species/line most adapted to the target host and to the environmental adversities (Vianna et al. 2011; Foresti et al. 2012).

Temperature is one of the most important abiotic factors, and it can affect parameters such as parasitism, life cycle duration, sex ratio, and parasitoid emergence (Pastori et al. 2008; Silva Júnior 2009; Paes 2015). Knowing thermal requirements of the parasitoid species makes it possible to predict and control parasitoid production (Pastori et al. 2012b). Knowledge of these thermal requirements allow for the determination of optimum temperatures for development of this natural enemy, as well as the estimation of the number of generations. This allows for planning and production/multiplication of hosts and parasitoids, making for synchronization and efficiency in production (Haddad et al. 1999; Pratissoli and Parra 2000).

Storing natural enemies at low temperatures is also a factor made possible through knowledge of the effect of temperature on the development of the parasitoid. This method promotes success in mass rearing, constant material for use in laboratory experiments, as well as release in the field at times of greatest occurrence of the insect pest targeted (Chen et al. 2008; Rodrigues and Sampaio 2011).

In this context, this study aimed to evaluate the impact of temperature on the biology of two lines of $T$. pretiosum, thus determining the thermal requirements of the parasitoids in eggs of $N$. elegantalis.

\section{Materials and methods}

The experiment was performed in the 'Laboratorio de Entomologia Aplicada (LEA)' of the 'Universidade Federal do Ceará (UFC)', Fortaleza, Ceará State, Brazil. Two lines of $T$. pretiosum ("Ubajara" and "Guaraciaba") were used, which were collected naturally parasitizing $N$. elegantalis eggs in tomato fruit in commercial areas in the region of 'Serra da Ibiapaba', Ceará State, Brazil (Oliveira et al. 2020). The first line was collected in the rural area in the municipality of Ubajara under a conventional tomato growing system, and the second line was collected in the municipality of Guaraciaba do Norte under an organic tomato growing system. The municipality of Ubajara is at $3^{\circ} 51^{\prime} \mathrm{S}, 40^{\circ} 55^{\prime} \mathrm{W}$, and 847.5 masl, with mean maximum temperature of $27.3^{\circ} \mathrm{C}$ and mean minimum of $16.0^{\circ} \mathrm{C}$. The municipality of Guaraciaba do Norte is at $4^{\circ} 10^{\prime} \mathrm{S}$, $40^{\circ} 44^{\prime} \mathrm{W}$, and 902.4 masl, with mean maximum temperature of $26.6^{\circ} \mathrm{C}$ and mean minimum of $15.6^{\circ} \mathrm{C}$.

Fabricio Fagundes Pereira, D. Sc., of the 'Universidade Federal da Grande Dourados (UFGD)' (Dourados, Mato Grosso do Sul State, Brazil) identified the parasitoid wasps and subsequently was confirmed by Ranyse Barbosa Querino, D. Sc., (Empresa Brasileira de Pesquisa Agropecuária, Secretaria de Inovação e Negócios', Distrito Federal, Brazil).

Biology of two lines of $T$. pretiosum exposed to different temperatures in eggs of $N$. elegantalis. To conduct the experiment, $N$. elegantalis eggs $(\mathrm{n}=40)$ were removed from scarlet eggplant (Solanum aethiopicum L.) using a moistened brush and glued onto sheets of sky-blue construction paper $(8.0 \times 2.0$ $\mathrm{cm})$ using arabic gum $(30 \%)$. The sheets were inserted in glass tubes $(8.5 \times 2.5 \mathrm{~cm})$ and then 4 females of $T$. pretiosum of 24 h-old were released. Females were fed with a drop of pure honey placed on the wall of the tubes. The tubes were closed with PVC ${ }^{\circledR}$ plastic film to prevent the parasitoid wasps from leaving. The eggs were exposed to parasitism for $24 \mathrm{~h}$ at $25 \pm$ $1{ }^{\circ} \mathrm{C}$, relative humidity of $70 \pm 10 \%$, and 12 -h photophase. After parasitizing the eggs, females were removed and the tubes were transferred to incubators under the same conditions cited above and exposed to $15,20,25,30$, or $35^{\circ} \mathrm{C}$, remaining until the emergence of the following generation of parasitoid wasps.

The percentage of emergence [(number of dark eggs with orifice/total number of parasitized eggs $) \times 100]$, sex ratio [number of females emerged/(number of females + males)], number of parasitoids emerged per egg (number of parasitoids emerged/total number of parasitized eggs), and life cycle duration (egg-adult) were the parameters evaluated. The experiment was set up in a completely randomized experimental design, with 5 treatments (temperatures) and 12 replicates (each tube constituting one replicate). An ANOVA oneway was conducted on the data and the means were compared by Tukey test $(\mathrm{P}<0.05)$. To biological parameters data, thermal requirements of the $T$. pretiosum lines were determined and the probable number of generations per year was calculated using the following equation: $N G=\left\{T\left(T_{m}-T b\right) / K\right\}$, where $\mathrm{K}=$ thermal constant, $\mathrm{T}_{\mathrm{m}}=$ mean monthly temperature 
for each location studied, $\mathrm{Tb}=$ base temperature $\left({ }^{\circ} \mathrm{C}\right)$, and $\mathrm{T}$ $=$ time (days). Relationship between temperature, time, and developmental rate of the "Guaraciaba" and "Ubajara" lines were determined by regression models.

\section{Results}

At $35^{\circ} \mathrm{C}$, development of $T$. pretiosum was not observed and, thus, continuity of the analyses using this temperature, aiming to evaluate the biological parameters and later determination of thermal requirements, was not possible.

The emergence of the two lines of $T$. pretiosum was affected by the temperatures, such that for the "Ubajara" line, a lower rate $(51.6 \%)$ was observed at the temperature of $15^{\circ} \mathrm{C}$. The other temperatures led to percentages higher than $80.0 \%$ (Table 1). For the "Guaraciaba" line, $25^{\circ} \mathrm{C}$ led to a viability rate of $98.9 \%$. The lowest viability was observed at $15^{\circ} \mathrm{C}$ $(64.9 \%)$. There was no difference for the temperatures among the lines examined (Table 1).

The sex ratio of the "Guaraciaba" line ranged from 0.54 to 0.73 , and the largest number of females was observed at 25 ${ }^{\circ} \mathrm{C}$. Effects of temperature were not observed on the sex ratio of the $T$. pretiosum "Ubajara" line (Table 1).

Regardless of the temperature and line used, emergence of 1.0 parasitoid per egg was observed (Table 1). The mean duration of the biological cycle (egg-adult) of the two lines was affected by the temperatures; there was reduction in this parameter with the increase in temperature. The longest duration cycle was observed at the temperature of $15^{\circ} \mathrm{C}(37.3$ days and 36.6 days) and the shortest at $30{ }^{\circ} \mathrm{C}$ (8.3 days and 7.7 days) for the "Ubajara" and "Guaraciaba" lines, respectively. The mean time for development of the parasitoids at 30 ${ }^{\circ} \mathrm{C}$ was $4.49,2.14$, and 3.84 times less than at 15,20 , and 25 ${ }^{\circ} \mathrm{C}$ for the "Ubajara" line; and 4.75, 2.34, and 3.97 times less under the same temperature conditions for the "Guaraciaba" line. The "Guaraciaba" line was superior to "Ubajara" regarding cycle duration in the temperature ranges studied (Table 1). From the results obtained for duration of the egg-adult phase of the $T$. pretiosum lines (Table 1), the lower thermal threshold for development $(\mathrm{Tb})$, the thermal constant $(\mathrm{K})$, and the number of generations per year in $N$. elegantalis eggs were calculated (Fig. 1).
For the lines tested, the thermal requirements were $\mathrm{Tb}$ of $10.77^{\circ} \mathrm{C}$ and $10.86^{\circ} \mathrm{C}, \mathrm{K}$ for the egg-adult phase of 153.85 and $142.86 \mathrm{GD}$, and 33.29 and 35.63 generations per year for the "Ubajara" and "Guaraciaba" lines, respectively. The values obtained for coefficients of determination $\left(\mathrm{R}^{2}\right)$ were 0.97 for the "Ubajara" line and 0.98 for "Guaraciaba", which therefore meet the value recommended by the hyperbolic method, which is $\mathrm{R}^{2} \geq 0.90$ (Table 2).

\section{Discussion}

When the parasitoids of the two lines were exposed to $35^{\circ} \mathrm{C}$, the lines did not develop because the metabolism and survival of the parasitoids are affected when, for example, the temperature is above that considered "optimal" for the species (Pastori et al. 2008).

The highest percentage of emergence was observed when the two lines of $T$. pretiosum were maintained at $25^{\circ} \mathrm{C}$, and the lowest percentage at $15^{\circ} \mathrm{C}$. The use of temperatures lower than $20^{\circ} \mathrm{C}$ result in a reduction in percent of emergence (Pratissoli and Parra 2000). The emergence rates of the "Ubajara" and "Guaraciaba" $T$. pretiosum lines was less than $70 \%$ at $15{ }^{\circ} \mathrm{C}$, denoting that this temperature range is not suitable for rearing the parasitoid in the laboratory aiming to achieve this parameter most effectively.

Other authors also found effects of temperature on the percentage of emergence of species of Trichogramma. The emergence of $T$. pretiosum in Sitotroga cerealella (Oliver, 1789) (Lepidoptera: Gelechiidae) eggs was lower (63.6\%) at $18^{\circ} \mathrm{C}$ than at $25^{\circ} \mathrm{C}(93.5 \%)$ (Inoue and Parra 1998). The percentage of emergence of $T$. pretiosum in Brazilian-apple-leafroller, Bonagota salubricola (Meyrick, 1937) (Lepidoptera: Tortricidae) eggs was $66.2 \%$ at $22{ }^{\circ} \mathrm{C}$ (Pastori et al. 2008). The temperature of $25^{\circ} \mathrm{C}$ was most adequate for percentage of emergence of T. atopovirilia Oatman \& Platner, 1983 (Hymenoptera: Trichogrammatidae) and $T$. pretiosum in citrus borer Ecdytolopha aurantiana (Lima, 1927) (Lepidoptera: Tortricidae) eggs (Molina et al. 2005).

A sex ratio greater than 0.50 was found in all treatments, and this value is considered appropriate for the quality control in mass rearing of Trichogramma spp. (Navarro 1998).

Table 1. Emergence (\%) (mean \pm standard error), sex ratio (mean \pm standard error), number of individuals (parasitoids) emerged per egg (mean \pm standard error), and duration (days) (mean \pm standard error) of the development cycle (egg-adult) of two Trichogramma pretiosum Riley (Hymenoptera: Trichogrammatidae) lines in eggs of Neoleucinodes elegantalis Guenée (Lepidoptera: Crambidae) at different temperatures.

\begin{tabular}{|c|c|c|c|c|}
\hline \multicolumn{5}{|c|}{ Temperature $\left({ }^{\circ} \mathrm{C}\right)$} \\
\hline Line & 15 & 20 & 25 & 30 \\
\hline \multicolumn{5}{|c|}{ Emergence (\%) } \\
\hline "Ubajara" & $51.65 \pm 5.62 \mathrm{Ab} 1$ & $85.25 \pm 3.62 \mathrm{Aa}$ & $92.49 \pm 4.39 \mathrm{Aa}$ & $86.29 \pm 9.53 \mathrm{Aa}$ \\
\hline "Guaraciaba" & $64.94 \pm 3.22 \mathrm{Ac}$ & $81.00 \pm 4.11 \mathrm{Ab}$ & $98.88 \pm 1.11 \mathrm{Aa}$ & $82.52 \pm 4.38 \mathrm{Ab}$ \\
\hline \multicolumn{5}{|c|}{ Sex ratio } \\
\hline "Ubajara" & $0.51 \pm 0.06 \mathrm{Aa}$ & $0.65 \pm 0.03 \mathrm{Aa}$ & $0.67 \pm 0.05 \mathrm{Aa}$ & $0.56 \pm 0.06 \mathrm{Aa}$ \\
\hline "Guaraciaba" & $0.54 \pm 0.04 \mathrm{Ab}$ & $0.66 \pm 0.02 \mathrm{Aab}$ & $0.73 \pm 0.03 \mathrm{Aa}$ & $0.68 \pm 0.04 \mathrm{Aab}$ \\
\hline \multicolumn{5}{|c|}{ Parasitoid/egg } \\
\hline "Ubajara" & $1.00 \pm 0.00$ & $1.00 \pm 0.00$ & $1.00 \pm 0.00$ & $1.00 \pm 0.00$ \\
\hline "Guaraciaba" & $1.00 \pm 0.00$ & $1.00 \pm 0.00$ & $1.00 \pm 0.00$ & $1.00 \pm 0.00$ \\
\hline \multicolumn{5}{|c|}{ Cycle duration } \\
\hline "Ubajara" & $37.30 \pm 0.15 \mathrm{Bd}$ & $17.40 \pm 0.16 \mathrm{Bc}$ & $9.70 \pm 0.15 \mathrm{Bb}$ & $8.30 \pm 0.15 \mathrm{Ba}$ \\
\hline "Guaraciaba" & $36.60 \pm 0.16 \mathrm{Ad}$ & $15.60 \pm 0.16 \mathrm{Ac}$ & $9.20 \pm 0.13 \mathrm{Ab}$ & $7.7 \pm 0.15 \mathrm{Aa}$ \\
\hline
\end{tabular}

${ }^{1}$ Means followed by the same lowercase letter in the line and uppercase letter in the column do not differ from each other by Tukey test at the level of $5 \%$ probability. 

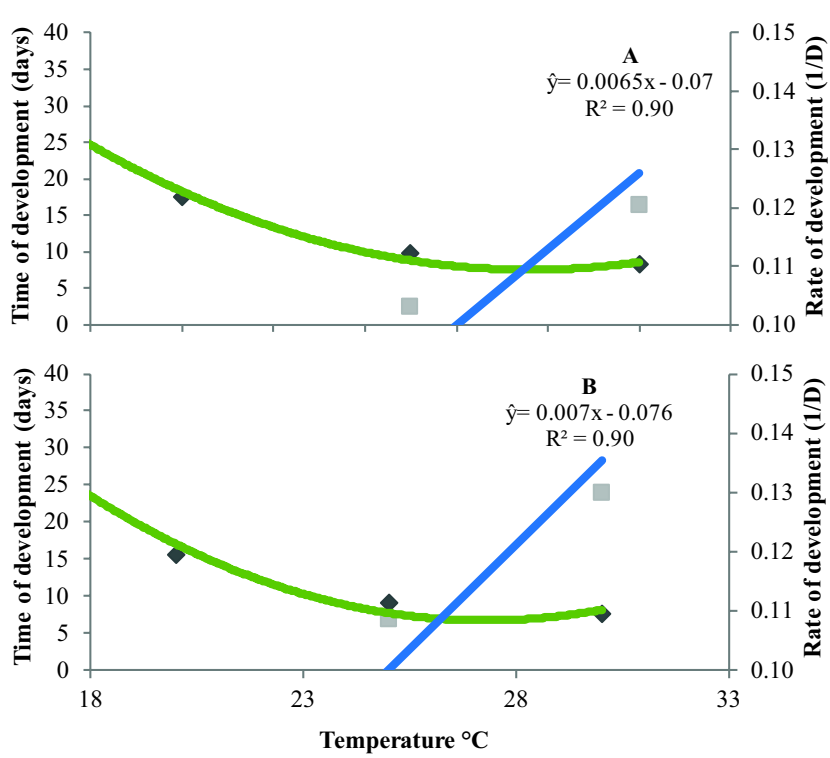

Figure 1. Relationship between temperature, time, and rate of development of Trichogramma pretiosum Riley (Hymenoptera: Trichogrammatidae) lines (A) "Ubajara", and (B) "Guaraciaba", in eggs of Neoleucinodes elegantalis Guenée (Lepidoptera: Crambidae).

The greater number of females in the present study may be attributed to the good development conditions provided by the host $N$. elegantalis. Among the thermal ranges studied, 25 ${ }^{\circ} \mathrm{C}$ for the "Guaraciaba" line, can be considered the ideal for obtaining the greatest number of females.

Other authors also confirmed the effect of temperature on sex ratio of T.pretiosum. Generally, there is a greater occurrence of males of Trichogramma spp. at temperatures greater than 30 ${ }^{\circ} \mathrm{C}$ (Bowen and Stern 1966). The sex ratio of the T. pretiosum LM line exhibited the highest number of females at $28{ }^{\circ} \mathrm{C}$ (Fonseca et al. 2005).

The number of parasitoids emerged per egg of $N$. elegantalis was 1 at all the temperatures studied, showing that the eggs of $N$. elegantalis have adequate size and nutritional quality for development of only one parasitoid per egg. The emergence of more than one individual per egg of the host may lead to parasitoids of smaller size and with inferior nutritional quality, due to intraspecific competition. This fact can compromise the performance of parasitoids under laboratory and field conditions (Moreira et al. 2009).

The life cycle (egg-adult) duration of the $T$. pretiosum lines "Ubajara" and "Guaraciaba" was inversely related to temperature increase. In addition to temperature, variation in cycle duration is affected by adaptation of the parasitoid species/line and host (Pereira et al. 2004).

An increase in degree-days at the higher temperature (30 ${ }^{\circ} \mathrm{C}$ ) is observed where a shorter development cycle is found. Cumulative degree-days are the number of degrees above a determined temperature that the organism needs for its development. Thus, it can be suggested that higher temperatures accelerate the biological cycle of the insects, such that they pass from one stage to another in shorter time compared to lower temperatures. However, lower temperatures reduce the insect metabolic processes, making for longer life cycle duration (Iowa State University 1987).

An inverse relationship between development time and temperature was also found by Paes (2015) in an experiment performed with $T$. pretiosum and T. galloi Zucchi, 1988 (Hymenoptera: Trichogrammatidae) in European
Table 2. Lower thermal threshold for development ( $\mathrm{Tb}$ ), thermal constant $(\mathrm{K})$, number of generations (per year), and coefficient of determination $\left(\mathrm{R}^{2}\right)$ of the egg to adult phase of two lines of Trichogramma pretiosum Riley (Hymenoptera: Trichogrammatidae) in eggs of Neoleucinodes elegantalis Guenée (Lepidoptera: Crambidae) at different temperatures.

\begin{tabular}{ccccc}
\hline Line & $\mathbf{T b}\left({ }^{\circ} \mathbf{C}\right)$ & $\mathbf{K}(\mathbf{G D})$ & $\begin{array}{c}\text { Number of generations } \\
\text { (per year) }\end{array}$ & $\mathbf{R}^{2}$ \\
\hline "Ubajara" & 10.77 & 153.85 & 33.29 & 0.97 \\
"Guaraciaba" & 10.86 & 142.86 & 35.63 & 0.98 \\
\hline
\end{tabular}

pepper moth Duponchelia fovealis Zeller, 1847 (Lepidoptera: Crambidae) eggs, and by Silva Júnior (2009) in an experiment with T. pretiosum, T. acacioi Brun, Moraes \& Soares, 1984 (Hymenoptera: Trichogrammatidae), and $T$. atopovirilia in eggs of the Brazilian-poplar-moth Condylorrhiza vestigialis (Guenée, 1854) (Lepidoptera: Crambidae) host. Life cycle duration ranged from 6.8 to 23.1 days for T. pretiosum in eggs of the diamondback moth Plutella xylostella (Linnaeus, 1758) (Lepidoptera: Plutellidae) at $32{ }^{\circ} \mathrm{C}$ and from 6.9 to 22.0 days for T. exiguum Pinto \& Platner, 1978 (Hymenoptera: Trichogrammatidae) at $18{ }^{\circ} \mathrm{C}$ (Pereira et al. 2004).

Determination of the temperature suitable for insect development is fundamental for rearing insects in the laboratory, as well as for adoption of control methods that make studies about biological aspects of the pests possible (Prezotti and Parra 2002). Through comparison of the thermal requirements of the "Ubajara" and "Guaraciaba" T. pretiosum lines obtained in this study, it can be predicted that throughout the year, the number of generations of the "Guaraciaba" line will be greater than that of the "Ubajara" line, a characteristic which is important for a biological control program.

The results obtained in the present study confirm the effect of temperature on the $T$. pretiosum lines collected in the "Serra da Ibiapaba" region and emphasize the importance of checking of this on biological parameters. This also indicates that temperature range most adequate for development of the T. pretiosum lines in N. elegantalis eggs was from 25 to $30^{\circ} \mathrm{C}$, in which the shortest egg-adult cycle was obtained.

\section{Acknowledgement}

To 'Conselho Nacional de Desenvolvimento Científico e Tecnológico (CNPq)', 'Coordenação de Aperfeiçoamento de Pessoal de Nível Superior (CAPES)', and 'Fundação Cearense de Apoio ao Desenvolvimento Científico e Tecnológico (FUNCAP)' for financial support.

\section{Literature cited}

BARROS, P. C. S.; COSTA, A. R.; SILVA, P. C.; COSTA, R. A. 2014. Torta de filtro como biofertilizante para produção de mudas de tomate industrial em diferentes substratos. Revista Verde de Agroecologia e Desenvolvimento Sustentável 9 (1): 265-270. https:// dialnet.unirioja.es/descarga/articulo/7337654.pdf

BENVENGA, S. R.; BORTOLI, S. A.; GRAVENA, S.; BARBOSA, J. C. 2010. Monitoramento da broca-pequena-do-fruto para a tomada de decisão do controle do tomateiro estaqueado. Horticultura Brasileira 28 (4): 435-440. https://doi.org/10.1590/S010205362010000400010

BERTI, J.; MARCANO, R. 1991. Preferencia de Trichogramma pretiosum Riley (Hymenoptera: Trichogrammatidae) por huevos de diferentes edades de varios hospederos. Boletín de Entomología Venezolana 6: 77-81. 
BOWEN, W. R.; STERN, V. M. 1966. Effect of temperature on the production of males and sexual mosaics in a uniparental race of Trichogramma semifumatum (Hymenoptera: Trichogrammatidae). Annals of the Entomological Society of America 59 (4): 823-834. https://doi.org/10.1093/aesa/59.4.823

CHEN, W. L.; LEOPOLD, R. A.; BOETEL, M. A. 2008. Cold storage of adult Gonatocerus ashmeadi (Hymenoptera: Mymaridae) and effects on maternal and progeny fitness. Journal of Economic Entomology 101 (6): 1760-1770. https://doi.org/10.1603/00220493-101.6.1760

FONSECA, F. L.; KOVALESKI, A.; FORESTI, J.; RINGENBERG, R. 2005. Desenvolvimento e exigências térmicas de Trichogramma pretiosum Riley (Hymenoptera: Trichogrammatidae) em ovos de Bonagota cranaodes (Meyrick) (Lepidoptera: Tortricidae). Neotropical Entomology 34 (6): 945-949. https://doi. org/10.1590/S1519-566X2005000600011

FORESTI, J.; GARCIA, M. S.; BERNARDI, O.; ZART, M.; NUNES, A. M. 2012. Biologia, seleção e avaliação de linhagens de Trichogramma spp. para o controle da lagarta-da-espiga em milho semente. EntomoBrasilis 5 (1): 1-6. https://doi.org/10.12741/ ebrasilis.v5i1.168

FORNAZIER, M. J.; PRATISSOLI, D.; SANTOS MARTINS, D. 2010. Principais pragas da cultura do tomateiro estaqueado na região das montanhas do Espírito Santo. pp. 185-226. In: INCAPER. Tomate. INCAPER, Vitória. Brazil. 430 p. http:// biblioteca.incaper.es.gov.br/digital/bitstream/item/793/1/LivroTomate-Incaper.pdf

GOMES, S. K. S.; CASTRO, M. T. 2017. Monitoramento de insetos em plantios de tomate com adubação silicatada. Biodiversidade 16 (3): 60-67. https://periodicoscientificos.ufmt. br/ojs/index.php/biodiversidade/article/view/6014

GOULART, R. M.; BORTOLI, S. A.; THULER, R. T.; PRATISSOLI, D.; VIANA, C. L. T. P.; VOLPE, H. X. L. 2008. Avaliação da seletividade de inseticidas a Trichogramma spp. (Hymenoptera: Trichogrammatidade) em diferentes hospedeiros. Arquivos do Instituto Biológico 75 (1): 69-77. https://repositorio.unesp. br/bitstream/handle/11449/2384/ZOORECZOOR14412073520. pdf? sequence $=3 \&$ isAllowed $=y$

GRAVENA, S.; BENVENGA, S. R. 2003. Manual prático para manejo ecológico de pragas do tomate. Gravena-ManEcol LTDA, Jaboticabal. Brazil. 1434 p.

HADDAD, M. L.; PARRA, J. R. P.; MORAES, R. C. B. 1999. Métodos para estimar os limites térmicos inferior e superior de desenvolvimento de insetos. FEALQ, Piracicaba. Brazil. 29 p.

INOUE, M. S. R.; PARRA, J. R. P. 1998. Efeito da temperatura no parasitismo de Trichogramma pretiosum Riley, 1879 sobre ovos de Sitotroga cerealella (Olivier, 1819). Scientia Agricola 55 (2): 222-226. https://doi.org/10.1590/S0103-90161998000200009

INSTITUTO BRASILEIRO DE GEOGRAFIA E ESTATÍSTICA (IBGE). 2018. Levantamento sistemático da produção agrícola. Instituto Brasileiro de Geografia e Estatística, Río de Janeiro, Brasil. https://sidra.ibge.gov.br/tabela/1618. [Review date: 02 May 2018].

IOWA STATE UNIVERSITY. 1987. Using degree days in an integrated pest management program. Iowa State University - University Extension - Ames, Iowa, Pat-1296. Available in: www. extension.iastate.edu/Publications/PM1296.pdf [Review date: June 1987].

LOOS, R. A.; SILVA, D. J. H.; FONTES, P. C. R.; COUTINHO PICANÇO, M. C. 2008. Identificação e quantificação dos componentes de perdas de produção do tomateiro em ambiente protegido. Horticultura Brasileira 26: (2): 281-286. https://doi. org/10.1590/S0102-05362008000200031

MOLINA, R. M. S.; FRONZA, V.; PARRA, J. R. P. 2005. Seleção de Trichogramma spp., para o controle de Ecdytolopha aurantiana com base na biologia e exigências térmicas. Revista Brasileira de Entomologia 49 (1): 152-158. https://doi.org/10.1590/S008556262005000100018
MOREIRA, M. D.; SANTOS, M. C. F.; BESERRA, E. B.; TORRES, J. B.; ALMEIDA, R. P. 2009. Parasitismo e superparasitismo de Trichogramma pretiosum Riley (Hymenoptera: Trichogrammatidae) em ovos de Sitotroga cerealella (Oliver) (Lepidoptera: Gelechiidae). Neotropical Entomology 38 (2): 237-242. https:// doi.org/10.1590/S1519-566X2009000200011

MOURA, A. P.; MICHEREFF FILHO, M.; GUIMARÃES, J. A.; LIZ, R. 2014. Manejo integrado de pragas do tomateiro para processamento industrial. Embrapa Circular Técnica n. 129, Embrapa Hortaliças, Brasilia. Brazil. 24 p.

NAVARRO, A. M. 1998. Trichogramma spp.: Producción, uso y manejo en Colombia. Guadalajara de Buga, Colombia. Impresos Técnicos Litográficos. $176 \mathrm{p}$.

OLIVEIRA, R. C. M.; PASTORI, P. L.; COUTINHO, C. R.; JUVENAL, S. O.; AGUIAR, C. V. S. 2020. Natural parasitism of Trichogramma pretiosum (Hymenoptera: Trichogrammatidae) in Neoleucinodes elegantalis (Lepidoptera: Crambidae) eggs on tomato (Solanales: Solanaceae) in the Northeast region, Brazil. Brazilian Journal of Biology 80 (2): 474-475. https://doi. org/10.1590/1519-6984.206676

PAES, J. P. P. 2015. Seleção e caracterização de Trichogramma (Hymenoptera: Trichogrammatidae) em Duponchelia fovealis Zeller (Lepidoptera: Crambidae). Dissertação Mestrado em Produção Vegetal. Universidade Federal do Espírito Santo. Alegre, Brazil. 83 p. http://repositorio.ufes.br/bitstream/10/4852/1/tese_7201_ Joao\%20Paulo\%20Pereira\%20Paes.pdf

PASTORI, P. L.; MONTEIRO, L. B.; BOTTON, M. 2008. Biologia e exigências térmicas de Trichogramma pretiosum Riley (Hymenoptera, Trichogrammatidae) "linhagem bonagota" criado em ovos de Bonagota salubricola (Meyrick) (Lepidoptera, Tortricidae). Revista Brasileira de Entomologia 52 (3): 72-476. https:// doi.org/10.1590/S0085-56262008000300024

PASTORI, P. L.; PEREIRA, F. F.; ANDRADE, G. S.; SILVA, R. O.; ZANUNCIO, J. C.; PEREIRA, A. I. A. 2012a. Reproduction of Trichospilus diatraeae (Hymenoptera: Eulophidae) in pupae of two lepidopterans defoliators of eucalypt. Revista Colombiana de Entomología 38 (1): 91-93. http://www.scielo.org.co/pdf/ rcen/v38n1/v38n1a15.pdf

PASTORI, P. L.; ZANUNCIO, J. C.; PEREIRA, F. F.; PRATISSOLI, D.; CECON, P. R.; SERRAO, J. E. 2012b. Desenvolvimento e exigências térmicas de Trichospilus diatraeae Cherian \& Margabandhu (Hymenoptera, Eulophidae) criado em pupas de Anticarsia gemmatalis (Hübner) (Lepidoptera, Noctuidae). Revista Brasileira de Biociências 10 (1): 79-85. http://www.ufrgs.br/seerbio/ ojs/index.php/rbb/article/download/1977/1092

PEREIRA, F. F.; BARROS, R.; PRATISSOLI, D.; PARRA, J. R. P. 2004. Biologia e exigências térmicas de Trichogramma pretiosum Riley e T. exiguum Pinto \& Platner (Hymenoptera: Trichogrammatidae) criados em ovos de Plutella xylostella (L.) (Lepidoptera: Plutellidae). Neotropical Entomology 33 (2): 231-236. https://doi.org/10.1590/S1519-566X2004000200014

PICANÇO, M. C.; BACCI, L.; CRESPO, A. L. B.; MIRANDA, M. M. M.; MARTINS, J. C. 2007. Effect of integrated pest management practices on tomato production and conservation of natural enemies. Agricultural and Forest Entomology 9 (4): 327-335. https://doi.org/10.1111/j.1461-9563.2007.00346.x

PRATISSOLI, D.; PARRA, J. R. P. 2000. Desenvolvimento e exigências térmicas de Trichogramma pretiosum Riley, criados em duas traças do tomateiro. Pesquisa Agropecuária Brasileira 35 (7): 281-1288. https://doi.org/10.1590/S0100-204X2000000700001

PREZOTTI, L.; PARRA, J. R. P. 2002. Controle de qualidade em criações massais de parasitóides e predadores. pp. 295-307. In: Parra, J. R. P.; Botelho, S. M.; Ferreira, B. S. C.; Bento J. M. S. (Eds.). Controle biológico no Brasil: Parasitoides e predadores. Manole, São Paulo. Brazil. 635 p.

RODRIGUES, S. M. M.; SAMPAIO, M. V. 2011. Armazenamento de Trichogramma pretiosum Riley (Hymenoptera: Trichogrammatidae) em baixas temperaturas. Arquivos do Instituto Biológico 78 (1): 45-51. https://doi.org/10.1590/1808-1657v78p0452011 
SILVA JÚNIOR, R. J. 2009. Capacidade de parasitismo e de desenvolvimento de três espécies de Trichogramma (Hymenoptera: Trichogrammatidae) em ovos de Condylorrhiza vestigialis (Lepidoptera: Crambidae). Dissertação Mestrado em Ciências Biológicas. Universidade Federal do Paraná. Curitiba, Brazil. 102 p. https://acervodigital.ufpr.br/handle/1884/18452?show=full

SIQUEIRA, J. R.; BUENO, R. C. O. F.; BUENO, A. F.; VIEIRA, S. S. 2012. Preferência hospedeira do parasitoide de ovos Trichogramma pretiosum. Ciencia Rural 42 (1): 1-5. https://doi. org/10.1590/S0103-84782011005000156

VIANNA, U. R.; PRATISSOLI, D.; ZANUNCIO, J. C.; ALENCAR, J. R. C. C.; ZINGER, F. D. 2011. Espécies e/ou linhagens de Trichogramma spp. (Hymenoptera: Trichogrammatidae) para o controle de Anticarsia gemmatalis (Lepidoptera: Noctuidae). Arquivos do Instituto Biológico 78 (1): 81-87. http://.doi. org/10.1590/1808-1657v78p0812011

WAJNBERG, E. 2010. Genetics of the behavioral ecology of egg parasitoids. pp. 150-159. In: Cônsoli, F. L.; Parra, J. R. P.; Zucchi, R. A. (Eds.). Egg parasitoids in agroecosystems with emphasis on Trichogramma. Springer, Dordrecht. Holland. 482 p.

\section{Origin and funding}

The origin of this article is from projects funded by "Conselho Nacional de Desenvolvimento Cientifico e Tecnológico (CNPq)", "Coordenação de Aperfeiçoamento de Pessoal de Nivel Superior (CAPES)" and "Fundação Cearense de Apoio ao Desenvolvimento Científico e Tecnológico (FUNCAP)".

\section{Author contribution}

Cristiane Ramos Coutinho; Suyanne Araújo de Souza; Antônia Débora dos Santos Pontes. Carried out experimental design, insect creations, lab experiments, statistical analyses and wrote the manuscript.

Mauricio Sekiguchi de Godoy. Performed the interpretation of the results and revised the manuscript.

Fabricio Fagundes Pereira. Modified and arranged of this article and performed the interpretation of the results.

Patrik Luiz Pastori. Analyzed the data, revised the manuscript and supervised the project. 